\title{
Tuberculosis of the thyroid gland associated with thyrotoxicosis
}

\author{
V.K. Kapoor, K. Subramani, S.K. Das, A.K. Mukhopadhyay and T.K. \\ Chattopadhyay
}

Department of Surgery, All India Institute of Medical Sciences, New Delhi 110029, India.

\begin{abstract}
Summary: Tuberculosis of the thyroid gland is rare. A case of tuberculosis of the thyroid gland associated with thyrotoxicosis is reported.
\end{abstract}

\section{Case report}

A 38 year old woman presented with weakness, heat intolerance and progressive loss of weight despite increased appetite for one and a half years. She also complained of insomnia, episodic diarrhoea, exertional dyspnoea and oligomenorrhoea of the same duration.

She was thinly built young female with a pulse rate of 100 beats $/ \mathrm{min}$ and blood pressure of $170 / 90 \mathrm{~mm} \mathrm{Hg}$. She had fine tremors of the fingers, brisk knee and ankle jerks and hypopigmented patches over both legs. Proptosis, lid lag and lid retraction were present. The thyroid gland was diffusely enlarged and soft in consistency, with a bruit and thrill. There was no cervical lymphadenopathy.

Haemoglobin was $11.2 \mathrm{~g} / \mathrm{dl}$, total leucocyte count $9.8 \times 10^{9} / 1$ and erythrocyte sedimentation rate $16 \mathrm{~mm}$ in the 1st hour. X-rays of the chest and the neck were normal. Protein bound iodine (PBI) was $11.4 \mu \mathrm{g} / \mathrm{dl}$ and $\mathrm{I}^{131}$ uptake $55.5 \%$ at $24 \mathrm{~h}$. Thyroid scan with $\mathrm{I}^{131}$ revealed diffuse enlargement of the gland with uniform uptake.

A diagnosis of thyrotoxicosis was made. Control of the toxic symptoms was achieved with carbimazole $(40 \mathrm{mg} / \mathrm{d})$ for 6 weeks. She also received Lugol's iodine for 10 days prior to surgery. Subtotal thyroidectomy was performed under general anaesthesia.

Histological examination of the specimen revealed diffuse hyperplasia of the thyroid with papillary projection of the lining epithelium and peripheral scalloping of the colloid. Scattered foci of epithelial cell granulomas with Langhans giant cells and central

V.K. Kapoor, M.S.; K. Subramani, M.B., B.S.; S.K. Das, M.S.; A.K. Mukhopadhyay, M.D.; T.K. Chattapodhyay, M.S.

Correspondence: T.K. Chattopadhyay

Accepted: 9 May 1984

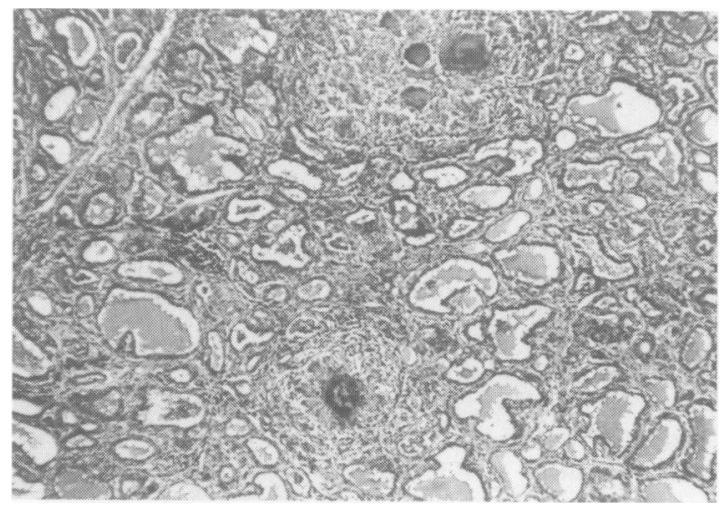

Figure 1 Hyperplastic follicles with papillary projection of the lining epithelium and peripheral scalloping of the colloid. Epithelial cell granulomas with central caseation necrosis and Langhans' giant cells are also seen (H.\&E. $\times 400)$

caseation necrosis were also seen in the interfollicular stromal tissue (Figure 1) Histological diagnosis of diffuse hyperplasia of the thyroid gland with coexisting tuberculosis was made.

Sputum, urine and gastric aspirate were repeatedly examined for acid fast bacilli - both on smear and culture - they were all negative. Skin test for tuberculosis (Mantoux) was positive.

The patient was put on anti-tuberculosis treatment and is doing well 9 months after the operation.

\section{Discussion}

Tuberculosis of the thyroid gland is rare. Goldfarb et al. (1965) reviewed 156 cases reported in the literature. Crompton \& Cameron (1969), Johnson et al. (1973), 
Laohapand et al. (1981) and Kukreja \& Sharma, (1982) have since reported single cases. Overall incidence of the disease 50 years ago was $0.1 \%$ to $0.4 \%$ of all thyroidectomy specimens (Coller \& Huggins 1926; Rankin \& Graham, 1932). Diagnosis of tuberculosis of the thyroid gland is rarely made clinically, a majority of the reported cases being diagnosed either postoperatively or at autopsy. The diagnosis is based on the presence of epithelial cell granulomas with peripheral lymphocytic cuffing, Langhans giant cells and central caseation necrosis. Granulomatous inflammation is also seen in de Quervains thyroiditis which is characterized by scattered disorganized follicles lined by necrotic epithelium, infiltration with neutrophils and macrophages and multinucleate foreign body giant cells (Symmers \& Wright, 1978). The presence of acid fast bacilli is confirmatory evidence of tuberculosis but it is not always possible to

\section{References}

COLLER, F.A. \& HUGGINS, C.B. (1926). Tuberculosis of the thyroid gland. Annals of Surgery, 84, 804.

CROMPTON, G.K. \& CAMERON, S.J. (1969). Tuberculosis of the thyroid gland mimicking carcinoma. Tubercle (London), 50, 61 .

GOLDFARB, H., SCHIFRIN, D. \& GRAIG, F.A. (1965). Thyroiditis caused by tuberculous abscess of the thyroid gland. American Journal of Medicine, 38, 825.

HIMSWORTH, R.L. \& KARK, A.E. (1977). Studies on a case of suppurative thyroiditis. Acta Endocrinologica, 85, 55.

JAFFE, R.H. (1930). Tubercle like structure in human goitre. Archives of Surgery, 21, 717.

JOHNSON, A.G., PHILIPS, M.E. \& THOMAS, R.J.S. (1973). Acute tuberculous abscess of the thyroid. British Journal of Surgery, 60, 668. find them. Tuberculosis of the thyroid gland may manifest as a nodule (Jaffe, 1930), thyroiditis (Laohapand et al., 1981), abscess (Johnson et al., 1973) and carcinoma (Crompton \& Cameron, 1969). Bacterial infections of the thyroid gland with abscess formation usually abolish uptake of isotopes by the gland (Himsworth \& Kark, 1977). The diffuse uptake of $I^{131}$ on scanning in the case reported here suggests a low grade infection without the formation of an abscess.

Clinical thyrotoxicosis in association with tuberculosis of the thyroid gland is rare (Mosiman, 1917). In the case reported here the patient had clinical features of thyrotoxicosis, and tuberculosis was incidentally discovered on histological examination of the thyroidectomy specimen. Their cause and effect relationship however could not be ascertained, and the thyrotoxicosis was presumed to be of auto-immune origin (Graves' disease).

KUKREJA, H.K. \& SHARMA, M.L. (1982). Primary tuberculosis of thyroid gland. Indian Journal of Surgerv, 44, 190.

LAOHAPAND, T., RATANARAPEE, S. CHANTARAKUL, N. \& VITAVASINI, A. (1981). Tuberculous thyroiditis - a case report. Journal of Medical Association of Thailand, 64, 256.

MOSIMAN, R.E. (1917). Tuberculosis of the thyroid gland Surgery, Gynecology \& Obstetrics, 24, 680.

RANKIN, F.W. \& GRAHAM, A.S. (1932). Tuberculosis of the thyroid gland. Annals of Surgery, 96, 625.

SYMMERS, W. ST C. \& WRIGHT, G.P. (1978). Systemi Pathology 2nd ed. Vol., 4, p. 2006, Churchill Livingstone: Edinburgh, London. 